\title{
Standardization of Robotic Grafting in Bell-Pepper (Capsicum annuum L. Var. Grossum Sendt.)
}

\author{
Shivanjali Sarswat ${ }^{*}$, Pardeep Kumar, Parveen Sharma and Vandana Thakur \\ Department of Vegetable Science and Floriculture, CSK Himachal Pradesh \\ Krishi Vishvavidalaya, Palampur - 176 062, India \\ *Corresponding author
}

\begin{tabular}{|l|}
\hline K e y w o r d s \\
Acclimatized,cotyle \\
don,ecofriendly, \\
robotic grafting, \\
rootstock, \\
sustainable
\end{tabular}

\section{A B S T R A C T}

Bell-pepper is a money spinner off season vegetable and is being exported to distant markets and brings profitable returns to the farmers. Manual grafting is labour intensive, time consuming and has poor grafting success as compared to robotic grafting, to accelerate grafting in vegetables, grafting robots are being used in some countries. The experimentation was laid out in a Factorial Randomized Block Design with three replications and data was recorded on various horticultural and quality traits. Treatment combination RS3A3 ensued lowest in days to first flowering and days to first harvest, showed significantly highest number of marketable fruits per plant, average fruit weight, marketable fruit yield per plant, marketable fruit yield per plot, fruit yield per hectare, fruit width, harvest duration and plant height. Whereas, maximum fruit length was recorded in RS1A3 Treatment. Grafting with scion and stock of as forty five days old was found the best seedling age combination.Data specified that there was no significant effect of interaction between rootstocks and seedling age on pericarp thickness $(\mathrm{mm})$. Scion variety 'Indra' was mechanically grafted on rootstock PI201232 has been found most suitable and can be recommended for further use

\section{Introduction}

Vegetable grafting has been safely adopted for the production of organic as well as environment friendly produce and diminishes uptake of undesirable agrochemical residues. In addition to the extensively recognized advantages of disease tolerance and high crop yields, grafting technology is also highly effective in ameliorating crop losses caused by adverse environmental conditions such as low soil temperature and high soil salts.

The use of resistant rootstocks diminishes dependence on agrochemicals, so the technique is consequently, considered to be ecofriendly for sustainable vegetable production (Rivard and Louws, 2008). The first robot, the "One Cotyledon Splice Grafting" system was developed in 1980s by 
lam Brain in Japan to graft cucurbit vegetables. Seedlings were cut at the point of attachment of the cotyledon to the hypocotyls at an angle of $20^{\circ}-30^{\circ}$ for the scion and the rootstock, respectively. The prototype grafting robot was constructed in 1987 and the second in 1989. It took 4.5 seconds to make a grafted plant with $95 \%$ survival. Prototype semi-automatic grafting system was also developed in Korea. Ashraf et al., (2011) developed a tomato seedling sorting algorithm for a full automatic grafting robot, with a $97 \%$ sorting success rate. A multiuse semiautomatic grafting machine has been developed by a private company in Korea; the machine has reasonable price, multiple functions and convenient handling.

In China, Zou et al., (2009) developed a rotary grafting machine that has a success rate of more than $88 \%$. In India, IIHR-Bengaluru is the first agricultural institute to install a semi-automatic grafting machine whereas; CSKHPKV-Palampur is the first agricultural university in the country to purchase a semiautomatic grafting robot for accelerating research and teaching work on vegetable grafting. This robot is supplied by Helper Robotech Co. Ltd., South Korea. It grafts 600-700 plants/hour with $90 \%$ accuracy. The other agricultural university which followed CSKHPKV is TNAU-Tamil Nadu, which also purchased and installed grafting robot to strengthen research work and teaching in vegetable grafting.

\section{Materials and Methods}

The investigation was undertaken in an open field condition at "Experimental Farm of Department of Vegetable Science and Floriculture", CSK Himachal Pradesh Krishi Vishvavidyalaya, Palampur during spring summer season in 2018. The experimental material for the present study comprised of five rootstocks of chilli namely AVPP0205,
PI-201232, Pant C-1, Surajmukhi, PBC-631 and a commercial hybrid of bell pepper 'Indra' was used as a scion. The gap in age of seedlings were maintained for scion at 30 days, 30 days, 45 days and for rootstocks 30 days, 45 days and 45 days. Sixteen treatments comprising of five rootstocks and 3 different seedling age and one control (non-grafted) were planted in a Randomized Block Design having 3 replications in 48 plots of $2 \mathrm{~m} \times 2 \mathrm{~m}$ size having 16 plants. Total area was 200 metre square in open field condition. First nursery sowing of rootstocks and scion seeds were done on 5 March, 2018 and second on 20 March 2018 for making 3 combinations of age of rootstocks and scion (30 days old scion and stock, 30 days old scion and 45 days old stock and 45 days old scion and stock). The grafting was done with Robotic Grafting Machine GR-600 CS. The scion and stock were inserted to the supplying parts. The machine conveys, cuts, and connects the two parts of plant. Grafted seedlings were kept in healing chamber to avoid wilting and accelerating healing process and then acclimatized to harden the seedlings.

Field was prepared and plants were planted at inter row distance of $45 \mathrm{~cm}$ and plant to plant distance of $30 \mathrm{~cm}$ in open field conditions. Before planting spot application of vermicompost in the pits was done. Five plants were randomly taken from each treatment in each replication for recording of data and the observation was recorded for various horticultural parameters.

\section{Results and Discussion}

Days to first flowering are an indicator of early fruiting which may result in early availability of the crop in the market. It is an important parameter in any vegetable crop which has significant contribution for securing early yields. A cursory glance at table 1. indicates that rootstocks and seedling 
age affected days to first flowering significantly. Scion variety Indra grafted on rootstock PI-201232 (RS3) took minimum number of days (37.44) to produce first flower, which are statistically superior to other plants grafted on different rootstocks. Plants grafted on rootstock RS3 (AVPP0205) took maximum number of days (43.56) to produce first flower.

Whereas, seedling age of rootstock A-3 (when both scion and stock were 45 days old) recorded minimum number of days (39.87) for first flower production and were statistically superior to all other seedling age. In comparison to non-grafted plants i.e. control, other treatment combinations took minimum days (48.33). Interaction effect was found with treatment RS3A3 (RS3 = PI201233 and $\mathrm{A} 3=45$ days old scion and 45 days old rootstock) took minimum 36.33 days for first flowering which was statiscally at par with RS3A1 (RS3 = PI-201233 and A1 = 30 days old scion and 30 days old rootstock) which took 37.67 days for first flowering.

However, as per table (1) the rootstocks used in the study and the age of seedlings affected number of days to first harvest significantly. Plants grafted on rootstock-RS3 (PI-201232) took minimum (57.56) days to produce marketable fruit which were statistically superior to all other rootstocks. In addition to this, A3 (45 days old rootstocks and scion) took minimum (60.93) days to first harvest which was statistically superior to other group of ages of seedlings.

As far as interaction among rootstocks and age of seedlings is concerned, significant variations were recorded. Minimum (56.67) days to first harvest were recorded in treatment RS3A3 (RS3 = PI-201232 and A1 = 30 days old scion and rootstock). Non-grafted plants i.e. control, took 7.67 days more to first harvest than other treatments. Numbers of marketable fruits per plants were significantly influenced by rootstocks and seedling age. As mentioned in table 1 . highest numbers of marketable fruits per plant (6.10) were recorded with rootstock PI-201232 (RS3), followed by RS5 (PBC-631) which recorded 4.49 fruits per plant. Highest number of marketable fruits per plant was found (4.11) when both rootstock and scion of 45 days age (A3) were grafted with robotic grafting machine.

It was significantly superior to A2 (3.90) where the age of scion and rootstock were 30 and 45 days, respectively. In this study, the interaction between age of rootstock and scion and different rootstock were found significant (Table 4.6). The maximum numbers of marketable fruits (6.25) per plant were recorded in treatment RS3A3 i.e.PI201232 was used as a rootstock and the age of both rootstock and scion was 45 days followed by RS3A2 treatment in which PI201232 was used as a rootstock and the age of scion and rootstock were 30 and 45 days, respectively (6.12). Control (non-grafted) plants recorded to produce 1.72 less fruits per plant than grafted plants.

The treatment RS3 (PI-201232) produced maximum average fruit weight i.e. $54.60 \mathrm{~g}$, followed by RS5 (PBC-631) which recorded $47.45 \mathrm{~g}$ fruit weight. Average fruit weight obtained with rootstock RS3 (PI-201232) was significantly high in comparison to other rootstocks used. Similarly, seedling age also affected the average fruit weight significantly. Treatment A3 (45 days old scion and 45 days old rootstock) recorded maximum average fruit weight $(47.27 \mathrm{~g})$ which was significantly higher than other treatments A1 (43.89 g) and A2 (44.48 g).

Interaction between rootstocks and grafting methods was found significant for this trait (Table 1). Maximum fruit weight (57.74 g) 
was obtained in the treatment RS3A3 $(\mathrm{RS} 3=$ PI-201232 and A3 = 45 days old scion and 45 days old stock) which was statistically superior to other treatments. Control (nongrafted) plants recorded to produce $7.05 \mathrm{~g}$ less average fruit weight than grafted plants. In addition to this, scion variety Indra grafted on rootstock RS3 with grafting robot (PI201232) produced maximum fruit yield per plant $(333.21 \mathrm{~g})$ followed by treatment RS5 (PBC-631) which recorded 213.25 g fruit yield per plant.

Whereas minimum yield was recorded in plants grafted on rootstock Pant C-1 (88.97 g). Rootstock RS3 (PI-201232) recorded $247.87 \mathrm{~g}$ more yield per plant than control (Non-grafted plants). Similarly, Seedling age also affected the fruit yield per plant significantly. Highest fruit yield per plant $(202.32 \mathrm{~g})$ was recorded in treatment A3 when both scion and rootstock were of 45 days old age at the time of grafting. It was significantly higher over A2 (181.15 g) where the age of scion and rootstock at the time of grafting was 30 days and 45 days respectively.

Interaction between rootstocks and seedling age were found to be significant for this trait. It was explicitly derived from the data presented in table 4.8 that highest fruit yield per plant (360.94 g) was observed in treatment RS3A3 (RS3 = PI-201232 and A3 = 45 days scion - 45 days rootstocks), which was followed by treatment RS3A2 (RS3 = PI201232 and A2 = 30 days scion - 45 days rootstock) which recorded $329.4 \mathrm{~g}$ fruit yield per plant (table 1.).

Yield per plot was significantly affected by different rootstocks used for grafting. Maximum yield $(5.33 \mathrm{~kg})$ per plot was obtained in plants with rootstock RS3 (PI201232) which was followed by RS5 (PBC631) which produced $3.38 \mathrm{~kg}$ yield was obtained per plot. Yield per plot obtained from plants grafted RS3 as rootstock was significantly higher than other rootstocks used. Similarly, age of seedling also influenced the yield per plot. Maximum yield (3.22 kg) per plot was obtained in A3 (45 days old scion and rootstock) followed by A2 (30 days old scion and 45 days old rootstock) from which yield per plot obtained was 2.90 $\mathrm{kg}$. The interaction between rootstocks and seedling age (Table 2.) were significant for this trait.

Maximum yield $(5.78 \mathrm{~kg})$ was exhibited in treatment RS3A3 (RS3 = PI-201232 and A3 = 45 days old scion and 45 days old rootstock) which was significantly higher than the other treatments. These results are in conformity with the findings of Jang et al., (2008), Kubota et al., (2008), Ballesta et al., (2010) and Saadoun and Allaagui (2013). Maximum fruit yield per hectare (133.28 q) was obtained when Indra scion was mechanically grafted on rootstock RS3 (PI-201232) followed by RS5 (PBC-631) which recorded yield of $84.48 \mathrm{q} / \mathrm{ha}$. Yield in plants grafted on Rootstock PI-201232 was significantly higher than all other rootstocks.

Similarly, seedling age also affected the fruit yield per hectare. Highest fruit yield per hectare $(80.50 \mathrm{q})$ were obtained when plants were grafted with robotic machine using 45 days old scion and stock (A3), which was significantly higher over other treatments. Interaction effect between rootstocks and seedling age was observed significant for fruit yield per hectare (Table 2.).

Maximum fruit yield per hectare (144.38 q) was obtained from treatment RS3A3 (RS3 = PI-201232 and A3 = 45 days old scion and 45 days old rootstock) which was significantly superior to other treatment combinations. Among rootstocks RS1 (AVPP0205) was found to produce maximum fruit length (7.17 
cm) followed by RS3 (PI-2012332) which recorded $6.60 \mathrm{~cm}$ long fruits. Fruit length obtained with RS1 (AVPP0205) as a rootstock was significantly higher over all other rootstocks used. Similarly, maximum fruit length $(6.40 \mathrm{~cm})$ was recorded when plants were grafted mechanically with 45 days old scion and 45 days old rootstock) (A3). Grafted plants recorded $0.35 \mathrm{~cm}$ more fruit length as compared to control.

Interaction effect between rootstocks and seedling age was also found to be significant (Table 2.). Highest fruit length $(7.38 \mathrm{~cm})$ was recorded in RS1A3 (RS1 = AVPP0205 and $\mathrm{A} 3=45$ days old scion and 45 days old rootstock) which was followed by RS1A2 (RS1 = AVPP0205 and A2 = 30 days old scion and 45 days old rootstock) which produced $7.22 \mathrm{~cm}$ long fruits. Similar findings were reported by Gisbert et al., (2011a) and Jang et al., (2012).

Nevertheless, maximum fruit width $(6.25 \mathrm{~cm})$ was recorded in plants mechanically grafted on RS3 (PI-201232) which was significantly higher than the other rootstocks used. It was followed by RS5 (PBC-631) which recorded fruit width of $6.17 \mathrm{~cm}$. Plants grafted on rootstock RS3 (PI-201232) recorded $0.81 \mathrm{~cm}$ more fruit width as compared to control. However, Indra scion grafted on rootstock RS2 (Pant C-1) and RS4 (Surajmukhi) were statistically at par with control.

Robotic grafting at different seedling age also significantly affected the fruit width. Maximum fruit width $(5.94 \mathrm{~cm})$ was recorded in A3 (45 days old scion and 45 days old rootstock) followed by A1 (30 days old scion and 30 days old rootstock) which recorded $5.76 \mathrm{~cm}$ fruit width. Significant interaction effect was found between rootstocks and seedling age for fruit width (Table 2.). Maximum fruit width $(6.38 \mathrm{~cm})$ was recorded in RS3A3 (RS3 = PI-201232 and A3 = 45 days old scion and 45 days old rootstock) which was statistically at par with RS5A3 (RS5 = PBC-631 and A3 = 45 days old scion and rootstock) which recorded fruit width of $6.31 \mathrm{~cm}$. Prolonged harvest duration is desired for obtaining higher return and also to avoid gluts in the market (table 2.).

Plants grafted through robotic machine on rootstock RS3 (PI-201232) recorded highest days (56.32) for harvest duration, followed by RS4 which recorded 52.13 days. Harvest duration of rootstock RS3 (PI-201232) was significantly more than other rootstocks used. Similarly, plants grafted with semiautomatic grafting machine at different age groups also affected harvest duration significantly.

Highest harvest duration of 47.98 days was recorded from plants grafted with 45 days old age of scion and stock (A3) which was significantly higher than the others. Grafted plants produced fruits for 2.03 days longer duration than the control. Interaction effect between rootstocks and seedling age was found to be significant for this trait (4.12).

Maximum harvest duration (58.53 days) was recorded in the treatment RS3A3 (RS3 = PI201232 and $\mathrm{A} 3=45$ days old scion and 45 days old rootstock) followed by harvest duration of 56.99 days in the treatment RS3A2 (RS3 = PI-201232 and A2 = 30 days old rootstock and 45 days old scion). The findings of Lee (1994) and King et al., (2010) corroborate the above results. Table 2 . indicate that plant height was significantly influenced by the different rootstocks used for grafting.

Maximum plant height of $52.52 \mathrm{~cm}$ was recorded in plants grafted mechanically on RS3 (PI-201232) which was followed by RS 1 (AVPP0205) with plant height of $47.63 \mathrm{~cm}$. Plant height obtained with RS3 (PI-201232) was significantly higher over all other rootstocks used. 
Table.1 Influence of rootstocks and seedling age on Days to first flowering, Days to first harvest, Number of marketable fruit/plant, Average fruit weight $(\mathrm{g})$ and Marketable fruit yield per plant $(\mathrm{g})$ in bell pepper

\begin{tabular}{|c|c|c|c|c|c|}
\hline Treatments & $\begin{array}{c}\text { Days to first } \\
\text { flowering }\end{array}$ & $\begin{array}{c}\text { Days to } \\
\text { first } \\
\text { harvest }\end{array}$ & $\begin{array}{c}\text { Number of } \\
\text { marketable fruit } \\
\text { per plant }\end{array}$ & $\begin{array}{c}\text { Average fruit } \\
\text { weight (g) }\end{array}$ & $\begin{array}{c}\text { Marketable } \\
\text { fruit yield per } \\
\text { plant (g) }\end{array}$ \\
\hline A. Rootstock & & & & & \\
\hline RS1 (AVPP0205) & 43.56 & 65.89 & 3.67 & 45.06 & 165.00 \\
\hline RS2 (Pant C-1) & 41.11 & 62.00 & 2.31 & 38.40 & 88.97 \\
\hline RS3 (PI-201232) & 37.44 & 57.56 & 6.10 & 54.60 & 333.21 \\
\hline RS4 (Surajmukhi) & 43.11 & 64.11 & 3.21 & 40.97 & 132.00 \\
\hline RS5 (PBC-631) & 40.22 & 60.44 & 4.49 & 47.45 & 213.25 \\
\hline CD (P=0.05) & 0.62 & 0.62 & 0.10 & 0.65 & 5.63 \\
\hline B. Seedling age & & & & & \\
\hline A1 (30-30) & 41.73 & 62.60 & 3.86 & 43.89 & 175.98 \\
\hline A2 (30-45) & 41.67 & 62.47 & 3.90 & 44.48 & 181.15 \\
\hline A3 (45-45) & 39.87 & 60.93 & 4.11 & 47.27 & 202.32 \\
\hline CD (P=0.05) & 0.48 & 0.48 & 0.08 & 0.51 & 4.36 \\
\hline C. Control vs. others & & & & & \\
\hline Control & 48.33 & 69.67 & 2.24 & 38.17 & 85.34 \\
\hline Others & 41.09 & 62.00 & 3.96 & 45.22 & 186.48 \\
\hline CD (P=0.05) & 0.78 & 0.79 & 0.13 & 0.83 & 7.12 \\
\hline
\end{tabular}

Table.2 Effect of rootstocks and seedling age on Marketable fruit yield/ plot (kg), Fruit yield/ hectare (q), Fruit length $(\mathrm{cm})$, Fruit width $(\mathrm{cm})$, Harvest duration (days) and Plant height (cm)in bell pepper

\begin{tabular}{|c|c|c|c|c|c|c|}
\hline Treatments & $\begin{array}{c}\text { Marketable } \\
\text { fruit yield/ plot }\end{array}$ & $\begin{array}{c}\text { Fruit yield/ } \\
\text { hectare (q) }\end{array}$ & $\begin{array}{c}\text { Fruit } \\
\text { length } \\
\text { (cm) }\end{array}$ & $\begin{array}{c}\text { Fruit } \\
\text { width } \\
\text { (cm) }\end{array}$ & $\begin{array}{c}\text { Harvest } \\
\text { duration } \\
\text { (days) }\end{array}$ & $\begin{array}{c}\text { Plant } \\
\text { height } \\
\text { (cm) }\end{array}$ \\
\hline A. Rootstock & & & & & & \\
\hline RS1 (AVPP0205) & 2.64 & 66.00 & 7.17 & 5.61 & 42.52 & 47.63 \\
\hline RS2 (Pant C-1) & 1.42 & 35.59 & 5.78 & 5.45 & 29.94 & 37.74 \\
\hline RS3 (PI-201232) & 5.33 & 133.28 & 6.60 & 6.25 & 56.32 & 52.52 \\
\hline RS4 (Surajmukhi) & 2.11 & 52.80 & 5.44 & 5.47 & 52.13 & 42.98 \\
\hline RS5 (PBC-631) & 3.38 & 84.48 & 6.00 & 6.17 & 44.27 & 45.83 \\
\hline CD (P=0.05) & 0.10 & 2.50 & 0.07 & 0.06 & 1.09 & 0.46 \\
\hline B. Seedling age & & & & & & \\
\hline A1 (30-30) & 2.81 & 70.36 & 5.99 & 5.76 & 42.92 & 44.61 \\
\hline A2 (30-45) & 2.90 & 72.43 & 6.21 & 5.66 & 44.21 & 44.66 \\
\hline A3 (45-45) & 3.22 & 80.50 & 6.40 & 5.94 & 47.98 & 46.75 \\
\hline CD (P=0.05) & 0.08 & 1.94 & 0.05 & 0.05 & 0.85 & 0.35 \\
\hline C. Control vs. others & & & & & & \\
\hline Control & 1.40 & 35.00 & 5.85 & 5.44 & 43.01 & 40.82 \\
\hline Others & 2.98 & 74.43 & 6.20 & 5.79 & 45.04 & 45.34 \\
\hline CD (P=0.05) & 0.13 & 3.16 & 0.09 & 0.07 & 1.38 & 0.58 \\
\hline
\end{tabular}




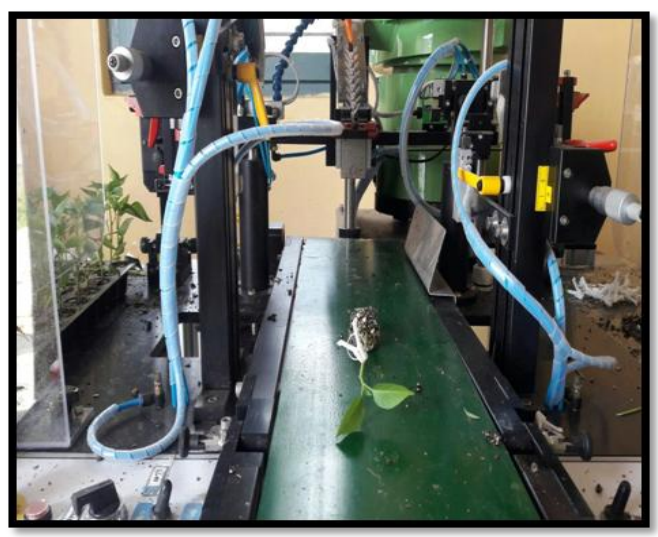

Fig.1 Semi-Automatic Robot

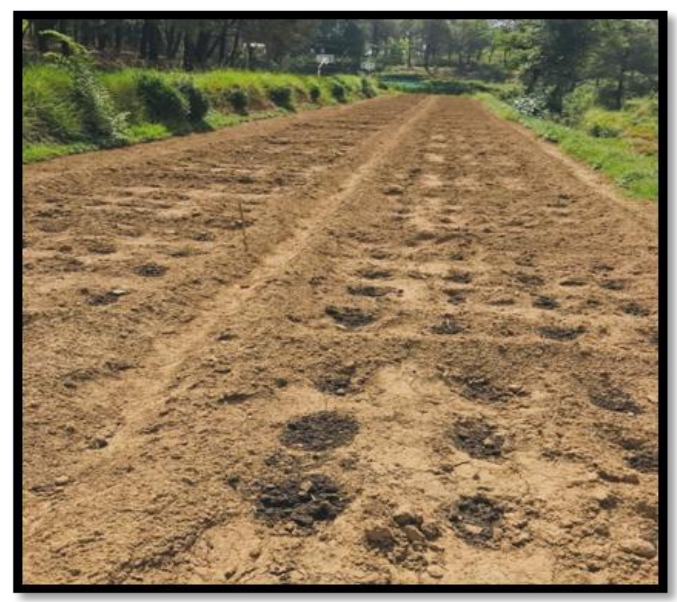

Fig.2 Experimental Layout
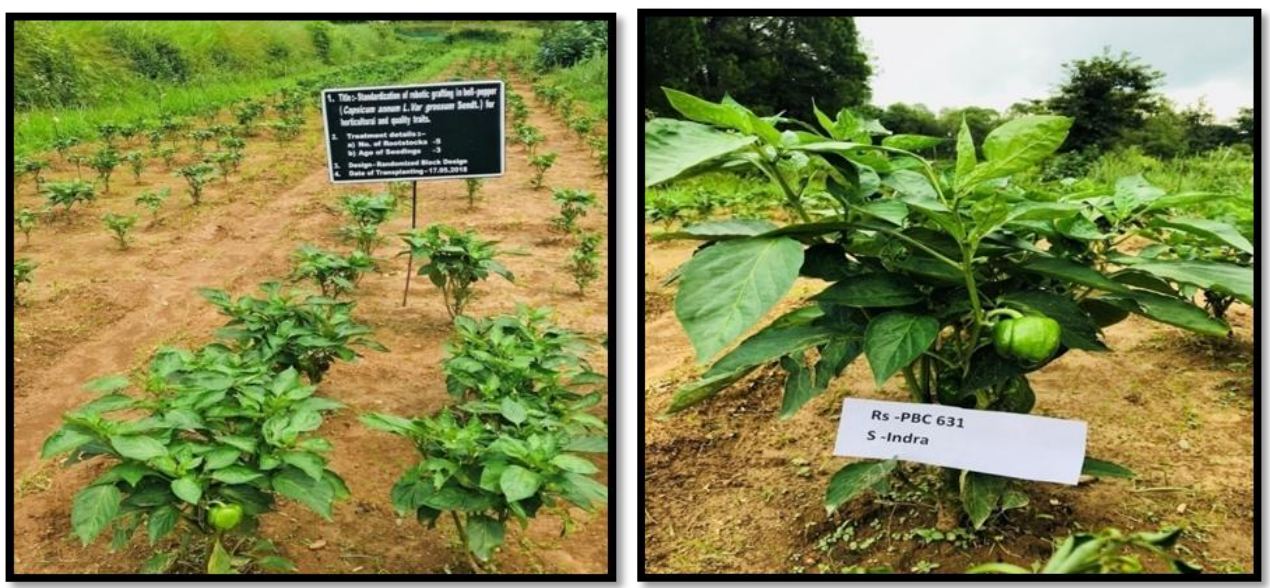

Fig.3 General View of Research Trial

Grafted plants recorded $4.52 \mathrm{~cm}$ higher plant height as compared to control. It shows that grafting slightly affected the plant height. Similarly, plants grafted with robot at different seedling age groups also affected the plant height significantly (Table 4.13). Maximum plant height $(45.34 \mathrm{~cm})$ was recorded when both scion and rootstock were grafted at 45 days age (A3). Interaction effect between rootstocks and seedling age for plant 
height was also found significant (Table 4.14). Highest plant height $(56.05 \mathrm{~cm})$ was recorded in treatment $\mathrm{RS} 3 \mathrm{~A} 3$ (RS3 $=\mathrm{PI}-$ 201232 and $\mathrm{A} 3=45$ days old scion and 45 days old rootstock) followed by RS3A2 (RS3 $=\mathrm{PI}-201232$ and $\mathrm{A} 2=30$ days old scion and 45 days old rootstock) recorded with plant height $51.28 \mathrm{~cm}$. Alike, results were reported by Khah et al., (2006), Passam et al., (2005) and Marin et al., (2013).

Robotic grafting is an effective technique to improve various horticultural and quality traits thereby, increasing total and early yield, improve vigour of plants and higher grafting success rate as compared to manual grafting. For robotic grafting the age of scion and stock should be same and about 45 days old age.

Maximum yield, quality and other horticultural traits were superior in plants when both scion and stock were 45 days old, when plants grafted on rootstock PI-201232, so this approach could be utilized as far as to improvise the status of grafting as an alternative technique in future and have numerous scope for further scientific developments.

\section{References}

Ashraf, M.A., Kondo, N. and Shiigi, T. 2011. Use of machine vision to sort tomato seedlings for grafting robot. Engineering in Agriculture, Environment and Food, 4(4): 119-125.

Ballesta, M.C.M., Lopez, C.A., Muries, B., Cadenas, C.M. and Carvajal, M. 2010. Physiological aspects of rootstock-scion interactions. Scientia Horticulturae, 127: 112-118.

Gisbert, C., Prohens, J. and Nuez, F. 2011a. Performance of eggplant grafted onto cultivated, wild and hybrid materials of eggplant and tomato. International Journal of Plant Production, 5(4): 367380.
Jang, Y., Yang, E., Cho, M., Um, Y., Ko, K and Chun, C. 2012. Effect of grafting on growth and incidence of phytophthora blight and bacterial wilt of pepper (Capsicum annum L.). Horticulture Environment Biotechnology, 53(1): 919.

Jang, Y., Yeol C.Y., Cheol, R.H. and Cheol, U.Y. 2008. Effects of rootstock and night temperature on the growth and yield of grafted pepper (Capsicum annum L.). Horticulture Environment and Biotechnology, 49(2): 63-71.

Khah, E.M., Kakava, E., Mavromatis, A., Chachalis, C. and Goulas, C. 2006. Effect of grafting on growth and yield of tomato (Lycopersicon esculentum Mill.) in greenhouse and open-field. Journal of applied Horticulture, 89(1): 3-7.

King, S.R., Davis, A.R., Zhang, X. and Crosby, K. 2010. Genetics, breeding and selection of rootstocks for solanaceae and cucurbitaceae. Scientia Horticulturae, 127: 106-111.

Kubota, C. and McClure, M.A. 2008. Vegetable grafting: History, use and current technology status in North America. Horticulture Science, 43(6): 1664-1669.

Lee, J.M.1994. Cultivation of grafted vegetables I. Current status, grafting methods, and benefits. Horticulture Science, 29(4): 235-239.

Marin, J.L., Gongalez, A., Alfocea, F.P., Gilabert, C.E. and Fernandez, J.A. 2013. Grafting is an efficient alternative to shading screens to alleviate thermal stress in greenhouse-grown sweet pepper. Scientia Horticulturae, 149: 3946.

Passam, H.C., Stylianou, M. and Kotsiras, A. 2005. Performance of eggplant grafted on tomato and eggplant rootstocks. European Journal of Horticulture Science,70(3): 130-134. 
Rivard, C.L. and Louws, F.J. 2008. Grafting to manage Soil borne Diseases in Heirloom Tomato Production. Horticulture Science, 43: 2008-2111.

Saadoun, M. and Allaagui, M.B. 2013. Management of chilli pepper root rot and wilt (caused by Phytophthora nicotianae) by grafting onto resistant rootstock. Phytopathologia Mediterranea, 52(1): 141-147.

Zou, G.Z., Suo, R.Y. and Gu, S. 2009. 2JC500 Rotary Vegetable Grafting Machine. Chinese Agriculture Mechanization, 1: 83-85.

\section{How to cite this article:}

Shivanjali Sarswat, Pardeep Kumar, Parveen Sharma and Vandana Thakur. 2020. Standardization of Robotic Grafting in Bell-Pepper (Capsicum annuиm L. Var. Grossum Sendt.). Int.J.Curr.Microbiol.App.Sci. 9(03): 1410-1418.

doi: https://doi.org/10.20546/ijcmas.2020.903.164 